\title{
Factors Influencing Income Smoothing Practices With Firm Size Moderation
}

\author{
Henryanto Wijaya, Mauren, and Hadi Cahyadi \\ Faculty of Economics and Business, Tarumanagara University \\ Email address: \\ henryantow@fe.untar.ac.id; lie.mauren@yahoo.com; hadic@fe.untar.ac.id
}

\begin{abstract}
The purpose of this study is to determine the effect of profitability, financial leverage, and dividend policy on income smoothing in manufacturing companies registered on the Indonesia Stock Exchange in 2016-2018 with firm size as a moderating variable. This study used 38 manufacturing companies as a sample in this study and analysis of logistic regression. The results of this study indicated that profitability has a significant negative effect on income smoothing; firm size has a significant positive effect on income smoothing. In contrast, financial leverage and dividend policy have an insignificant effect on income smoothing. Firm size weakens profitability and the effect of dividend policy on income smoothing while firm size does not moderate financial leverage's effect on income smoothing.
\end{abstract}

Keywords: profitability, financial leverage, dividend policy, income smoothing, firm size.

\begin{abstract}
Abstrak: Penelitian ini memiliki tujuan untuk mengetahui pengaruh profitabilitas, financial leverage, dan kebijakan dividen terhadap praktik perataan laba pada perusahaan yang bergerak di bidang manufaktur yang terdaftar di Bursa Efek Indonesia tahun 2016-2018, dengan ukuran perusahaan sebagai variabel moderasi. Dalam penelitian ini, terdapat 38 perusahaan manufaktur sebagai sampel di mana analisis regresi logistik dilakukan. Hasil dari penelitian ini menunjukkan bahwa profitabilitas memiliki pengaruh negatif dan signifikan terhadap praktik perataan laba; ukuran perusahaan memiliki pengaruh positif dan signifikan terhadap praktik perataan laba. Sebaliknya, leverage keuangan dan kebijakan dividen memiliki pengaruh yang tidak signifikan terhadap praktik perataan laba. Ukuran perusahaan memperlemah profitabilitas dan pengaruh kebijakan dividen terhadap perataan laba sedangkan ukuran perusahaan tidak memoderasi pengaruh leverage keuangan pada perataan laba.
\end{abstract}

Kata Kunci: profitabilitas, financial leverage, kebijakan dividen, income smoothing, ukuran perusahaan.

\section{INTRODUCTION}

The financial statements describe the state of the company performance in the financial reporting process in one period containing the company's financial information for internal and external parties. External parties, such as investors and creditors, use this 
knowledge to support them with their decision-making. The financial statements of a company consist of five components: 'income statement', statement of changes in equity, the balance sheet at the end of the year, the cash flow statement, and the financial report notes in the form of company financial information (IAI, 2017).

Companies use financial reports to see the development of company financial statement information in terms of profits. We can see the criteria for companies in seeing company profits from the performance of management in stabilizing profits, which makes investors interested in investing (Indrawan et al., 2018). The management has the opportunity to perform dysfunctional behavior through income smoothing practices (Handoyo and Fathurrizki, 2018).

In adopting income smoothing practices, the company's goal is to improve the stability of earnings to the target rate. There are two types of profit earnings practices: (1) Efforts to increase profits in the company income statement to improve the company performance for the better; (2) Efforts to reduce profit in the company income statement to reduce the tax liability that the company must pay (Indrawan et al., 2018).

The practice of income smoothing will result in improper disclosure of earnings if done on purpose. It results in investors' obtaining a low level of accuracy and insufficient information about earnings to evaluate the results and risks of their portfolios (Paramita and Isarofah, 2016).

The income smoothing practice in Indonesia is quite frequent, one of which is as done by one of the banks in Indonesia. The bank revised its 2015-2017 financial statements, and it received special attention from the Indonesia Stock Exchange and the Financial Services Authority (OJK). The stock exchange authorities would determine whether to impose sanctions when they saw significant differences in the financial statements that have not been revised with the financial statements after the revisions. IDX Director of Corporate Assessment, Samsul Hidayat, said that he would confirm this to the responsible auditor. If proven that there was a significant difference, they would determine why this took place (Rachman; 2018; finance.detik.com).

Income smoothing has a connection with earnings management, and both methods use the agency theory as their guide. However, when we apply agency theory in earnings management, a potential conflict of interest may take place between the agent (management) and the owners (Indrawan et al., 2018).

Several factors influence income smoothing practices: profitability, leverage, dividend policy, and firm size. The first factor is profitability, which is the ability of a company to earn profits over a period and tests the performance of its management (Kasmir, 2015). Profitability is a measure for investors to compare the company's performance. It can surely help them in making decisions in the future. Companies also conduct income smoothings to make their finances more stable, even if profitability level is not extremely high. (Indrawan et al., 2018).

The second factor, leverage, means the company's ability to pay off corporate debt when buying and financing assets if the leverage in a company shows a high ratio, the greater the risk for investors to pay off debt (Dewantari and Badera, 2015).

The next factor is the dividend policy, which means the decisions on the profit received by a corporation are linked to the payment of profits as dividends for potential investments. (Widhyawan and Dharmadiaksa, 2015). The profit reserve will decrease when the company distributes profits as dividends. Conversely, if the company retains all profits 
and does not distribute dividends, the interests of the shareholders will be neglected (Paramita and Isarofah, 2016).

The fourth factor is firm size, which means the scale is calculated by adding total assets and sales. The greater the total number of assets and sales the company has, this means that the company has a better performance in order to generate funds to pay off company debts. (Fatmawati and Djajanti, 2015).

\section{THEORETICAL REVIEW}

Agency Theory. (Schroeder et al., 2010) stated that agency theory is a deliberate relationship between two parties, which entails one party (agent) working in place of the other party (agent). This partnership between shareholders and managers takes place because the founders do not have the full capacity to run the business themselves. As a result, someone else had to be hired to replace their role. These people are agents entrusted with making decisions in the best interests of shareholders.

Based on agency theory, the relationship between shareholders and managers will create a conflict of interest. Managers may make accounting alternatives that cause accounting income to increase because managers want to profit through company revenue. In this case, the interests of the shareholders to get as much wealth as possible are not fulfilled. Shareholders' wealth is even reduced because the compensation for the manager is greater than it should be (Schroeder et al., 2010).

Management within the company must have information that has been tracked internally by the company. It is difficult for companies to obtain accurate information between shareholders as information users and agents as information providers, which is called information asymmetry. Consequently, communication between shareholders and agents becomes unstructured because external parties may present inappropriate information to shareholders (Paramita and Isarofah, 2016).

One of the agents' actions to maximize their interests by taking advantage of the information asymmetry is to conduct income smoothing (Paramita and Isarofah, 2016). In reality, investors are very concerned with profits in the form of investment returns in their business. Management will be able to fulfil the wishes of investors and will receive financial compensation in return if management manipulates earnings by practising income smoothing. (Handoyo and Fathurrizki, 2018).

Positive Accounting Theory. (Scott, 2014) stated that Positive Accounting Theory means a theory that projects the actions associated with the choosing of corporate accounting policies and how companies will respond to the proposed new accounting principles. It provides a scientific explanation from the knowledge, ability, and understanding of accounting through accounting policies to deal with future conditions.

The positive theory of accounting makes predictions broadly governed by three hypotheses, as constructed by (Scott, 2011). The first hypothesis is the bonus plan hypothesis, which states that when everything else is assumed to be constant, company managers with bonus plans tend to choose accounting measures that move the income statement from future term to ongoing term. This hypothesis seems quite plausible. Managers inevitably want high returns and depend on bonuses that are tied to reported profits. Companies can increase their bonuses by making the highest possible net income 
statement by choosing accounting policies that increase reported profit. The second hypothesis is the debt covenant hypothesis, which also considers everything else in a constant state. The closer the business comes to breach accounting-based debt deals, the more likely it is for corporate management to take accounting actions, such as transferring reported profits from future times to current periods. The explanation for the debt contract hypothesis is that the rise in the reported benefit would minimize technical errors. Most debt contracts contain conditions that the borrower must fulfil. If these provisions are violated, the borrower will be fined. Company management should avoid breaching debt contracts by using accounting policies to increase current period profits. Third, the hypothesis is the political cost hypothesis, which also states that all other things are considered constant. The greater the political costs that the company faces, the greater the manager will take accounting measures that defer profits from present to future periods. The size and level of high profitability of the company can lead to greater political costs. The way to avoid the political cost hypothesis is to use accounting policies that can reduce profits to convince the government that companies do not have a large profit and can reduce political costs.

Earnings management. (Wolk et al., 1992), defined earnings management as the intervention in the process of external financial reporting to achieve personal benefit. According to (Scott, 2011), earnings management take into four forms: (1) Taking a bath can occur during a period when there is pressure on an organization or reorganization occurs. This approach allows the existing expenses to be remembered in the present era in subsequent years. As a result, the profit in the future period is high despite being in the loss. (2) Income minimization is similar to taking a bath less extremely. This technique is carried out because of political motives, carried out when the company shows a high level of profitability so that it does not get political attention. (3) Income maximization aims to generate bigger bonuses and avoid breaching long-term debt contracts. (4) Income smoothing aims to report constant profits from one period to the next, rather than showing a drastic increase or decrease in profit.

(Wild et al., 2013) remarked that conducting income smoothing is one form of earnings management, wherein this policy, managers increase or decrease reported earnings to reduce fluctuations in company profits.

There are many reasons why income smoothing is done. One of them is that investors prefer a stable profit because it reflects the company's stability, strength, and growth. Since investors prefer this, income smoothing causes share prices to be higher (Mathews and Perera, 1996).

According to (Mathews and Perera, 1996), income smoothing can fall into two practices: original and artificial. In original income smoothing, income smoothing was manipulated through real transactions by delaying or expediting transactions. Conversely, in artificial income smoothing, income smoothing is carried out through the accounting steps of moving costs or income from one period to another by changing accounting policies.

(Paramita and Isarofah, 2016) stated that profitability is the capability of a business to earn income calculated by the correlation between the profit after tax and the total assets (or "return on assets"). It is essential to assess "Return on Assets" (ROA) to determine whether or not the company's financial statements are sound and can influence investors' decisionmaking process. A greater change in ROA can be interpreted as a greater fluctuation in the 
level of management's ability to generate profits. It affects investors in predicting profit and risk in investment, which affects the level of investor confidence in a company (Doraini and Wibowo, 2017).

According to (Wild et al., 2013), profitability analysis is an evaluation of profits obtained in financial reports that affect company investment. This analysis focuses on the company's resources and profits and includes identifying and measuring the impact of the factors that affect profitability.

(Wild et al., 2013) wrote that financial leverage means using debts to increase profits. Leverage increases the rate of success (profit) as well as management failure (loss). Companies with financial leverage are often referred to as companies that carry out trading activities of equity. It shows that the basis for corporate loans to get a return lies more in using the company's equity capital.

The leverage ratio functions as a measurement of how much influence the company's assets have on equity. Companies with high leverage ratios finance their assets using debt and liabilities and have a higher risk than companies with lower leverage ratios (Paramita and Isarofah, 2016).

A dividend strategy decides whether the company will allocate its profits to owners in the form of dividends or whether it will keep them as retained earnings to fund future investment. When the company pays dividends, it means that the company ignores the reserve's interest. Conversely, companies that make retained earnings will result in all shareholders not getting dividends. Financial managers must be able to make the best dividend policy (Paramita and Isarofah, 2016).

The company's dividend payout ratio (DPR) is a measure of dividend policy. This measuring tool can show the net income percentage paid during the year in cash dividends (Handoyo and Fathurrizki, 2018). Companies with high DPR can be interpreted as companies that can provide high returns to investors (Paramita and Isarofah, 2016).

Firm size is a measure to classify firm size in several ways, including the natural logarithm of total assets (Indrawan et al., 2018). There are three categories of firm size: large-size firms, medium-sized firms, and small-size firms.

Total assets can be a proxy for measuring firm size with high accuracy (Fatmawati and Djajanti, 2015). Total assets reflect the company's wealth, meaning that company size depends on the overall asset amount. The following picture is the framework used in this study: 


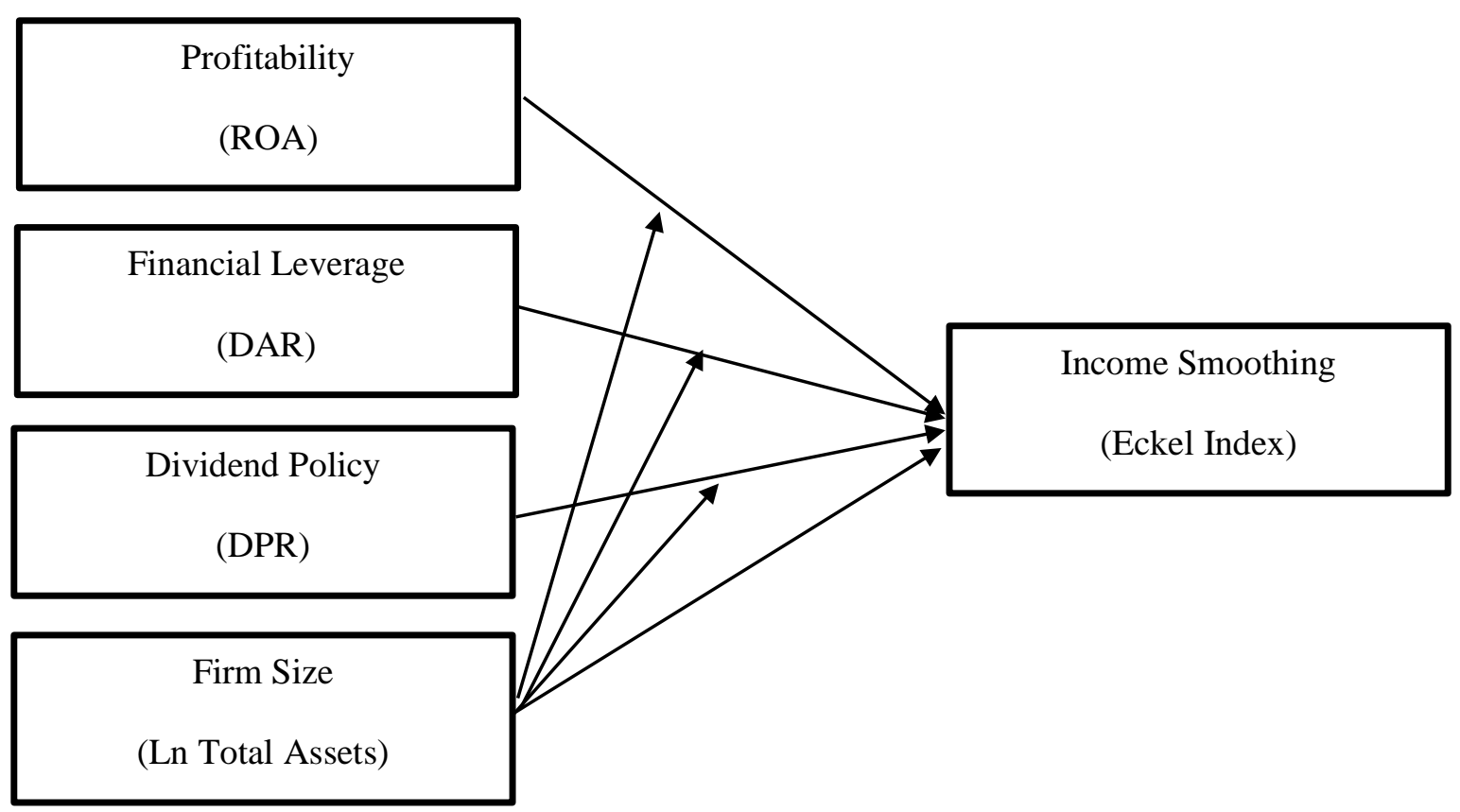

Figure 1. Framework

From the model built above, the hypotheses are listed below:

$\mathrm{H}_{1}$ : Profitability has a positive and significant effect on income smoothing.

$\mathrm{H}_{2}$ : Financial leverage has a positive and significant effect on income smoothing.

$\mathrm{H}_{3}$ : Dividend policy has a positive and significant effect on income smoothing.

$\mathrm{H}_{4}$ : Firm size has a positive and significant effect on income smoothing.

$\mathrm{H}_{5}$ : Firm size significantly strengthens the effect of profitability on income smoothing.

$\mathrm{H}_{6}$ : Firm size significantly strengthens the effect of financial leverage on income smoothing.

$\mathrm{H}_{7}$ : Firm size significantly strengthens the effect of dividend policy on income smoothing.

\section{METHODS}

The research subject focuses on all listed companies on the Indonesia Stock Exchange for 2016-2018, in which the financial reports are obtained from www.idx.co.id. This research aims at profitability, financial leverage, dividend policy, firm size, and income smoothing. The purposeful sampling method is a sample collection method with the parameters defined in the sample, namely: (1) Manufacturing companies were listed on the Indonesia Stock Exchange in 2016-2018, (2) Companies that present complete financial statement data on the Indonesia Stock Exchange during 2016-2018, (3) Companies that did not experience consecutive losses during the 2016-2018 period, (4) Companies that distributed cash dividends during 2016-2018 consecutively, (5) Companies that show financial statements in Rupiah currency during 2016-2018.

This study has operating variables, including profitability, financial leverage, and dividend strategy, which are independent, income smoothing as a dependent variable, and company size as a moderating variable. In particular, the act of income smoothing in this analysis is expressed by the "Eckel Index" using the formula: 


\section{Income Smoothing Calculation:}

Eckel Index $=\frac{\mathrm{CV} \Delta \mathrm{I}}{\mathrm{CV} \Delta \mathrm{S}}$

Notes:

$\Delta \mathrm{I}=$ Changes in profit over a time period

$\Delta \mathrm{S}=$ Changes in income in a time period

$\mathrm{CV}=$ The coefficient of variation of the variables

$\mathrm{CV} \Delta \mathrm{I}=$ The coefficient of variation for changes in earnings

$\mathrm{CV} \Delta \mathrm{S}=$ Coefficient of variation for changes in Income

In this study, the calculation of profitability will be carried out using the return on assets (ROA) calculation formula as follows:

Calculating Profitability:

$\mathrm{ROA}=\frac{\text { Net Profit }}{\text { Total assets }} \times 100 \%$

Notes:

$\mathrm{ROA}=$ Return on assets

The financial leverage calculation uses the debt to total assets ratio (DAR) formula as follows:

\section{Calculating Financial Leverage:}

DAR $=\frac{\text { Total amount of debt }}{\text { Total assets }} \times 100 \%$

Notes:

$\overline{\mathrm{DAR}}=$ Debt to assets ratio

The dividend policy calculation uses the dividend payout ratio (DPR) formula as follows:

\section{Calculating Dividend Policy:}

DPR $=\frac{\text { Cash Dividend }}{\text { Net Profit }}$

Notes:

$\overline{\mathrm{DPR}}=$ Dividend Payout Ratio

The formula of calculating the size of the company in this study is:

\section{Calculating Firm size}

Firm size $=\log n$ total assets 
The data analysis approach used is descriptive statistics and analysis of logistic regression. This study used a logistic regression test since the dependent variable was a dummy variable in this study.

Descriptive statistics. Descriptive statistics are data analysis that aims to describe quantitative data to obtain clarity of information in decision making by looking at the 'average value, maximum value, minimum value, and standard deviation value' (Ghozali and Ratmono, 2013). The average value is the sum of the overall data divided by the number of data obtained. The minimum value shows an approximate description of each variable's lowest value, while the maximum value describes the estimated highest value of each variable. Then, the standard deviation value estimates the distribution of data to the average value in the study.

Logistic Regression Analysis. The influence of these variables on income smoothing practices can be seen using logistic regression analysis or logit models. The logit model analyzes the dependent variable with a dichotomy scale, namely the scale of nominal data with two categories (for example, 'yes or no', 'good or bad', or 'high or low').

In logistic regression analysis, data normality assumptions and classical assumption tests on the independent variables are not required. The explanatory variables do not have to be normally distributed, linear, or have the same variance in each grip (Ghozali, 2011).

The qualitative response regression model, also known as the probability model, does not require a normality assumption test. Like the dependent variable, the residual variable has two values following the Bernoulli probability distribution, namely: 1 if the event occurs and 0 if the event does not occur. Logistic regression also ignores heteroscedasticity (Gujarati and Porter, 2012).

(Kuncoro, 2001) noted several advantages of the logit model compared to other analysis techniques, namely: (1) The logit model does not require the test of normality and heteroscedasticity assumption on the independent variables used because there is more than one independent variable of the research. (2) In logistic regression, the independent variables can be a mixture of several variables, such as continuous, discrete, and dichotomous variables. Continuous variables are variables that, when measured, will produce continuous data such as ordinal data, intervals, and ratios. Discrete variables are variables that, if measured, will produce nominal data. If the discrete variable consists of only two categories (for example, yes or no), it is called a dichotomous variable. (3) Logistic regression does not require the limitations of its independent variables. (4) Logistic regression also does not require that the independent variable be an interval scale.

To test which variables affect income smoothing practice, Microsoft Excel 2010, and EViews 10 software were used as a data processing tool. The research model employed is as follows:

$\ln \left[\frac{\mathrm{Pi}}{1-\mathrm{Pi}}\right]=\beta_{0}+\beta_{1} \mathrm{X} 1+\beta_{2} \mathrm{X} 2+\beta_{3} \mathrm{X} 3$

Notes:

$\ln \left[\frac{\mathrm{Pi}}{1-\mathrm{Pi}}\right] \quad=$ Probability ratio

$\mathrm{Pi}=$ The probability of the company running income smoothing 


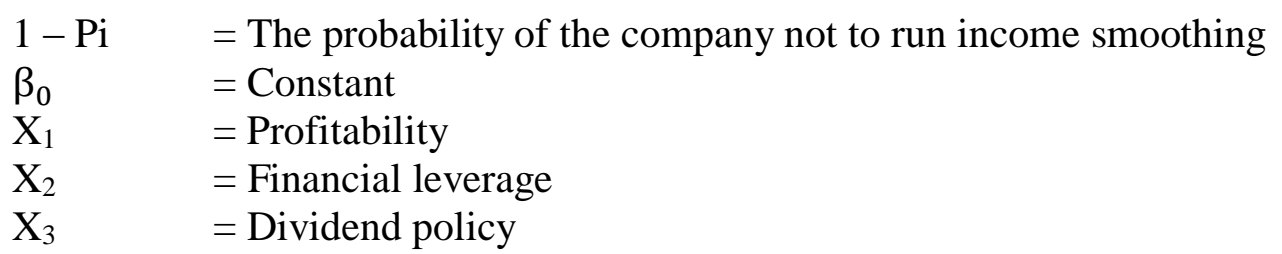

The second research model is a research model using moderating variables, namely as follows:

$\ln \left[\frac{\mathrm{Pi}}{1-\mathrm{Pi}}\right]=\beta_{0}+\beta_{1} \mathrm{X} 1+\beta_{2} \mathrm{X} 2+\beta_{3} \mathrm{X} 3+\beta_{4} \mathrm{X} 4+\beta_{5} \mathrm{X} 1 . \mathrm{Xm}+\beta_{6} \mathrm{X} 2 . \mathrm{Xm}+\beta_{7} \mathrm{X} 3 . \mathrm{Xm}$

Notes:

$\mathrm{X}_{4} / \mathrm{X}_{\mathrm{m}}=$ Firm size

The Coefficient of Determination $\left(\mathbf{R}^{2}\right)$. The $R$ square $\left(R^{2}\right)$ determines how big the proportion of the contribution between the variables of independent and the dependent variable. The greater the relationship between the dependent variable and the independent variable, the greater is the $\mathrm{R}^{2}$ (Nachrowi, 2006).

The use of EViews creates the "McFadden $\mathrm{R}^{2}$ coefficient of determination". It is used to see how much change in the dependent variable may be represented by adjusting the independent variable value. This value calculates the regression model's success rate to make a prediction on the value of the dependent variable or to know the fitness of the model. The $\mathrm{R}^{2}$ has a value range of zero to one $\left(0<\mathrm{R}^{2}<1\right)$. If the value of $\mathrm{R}^{2}$ is close to one, which means that the dependent variable can be explained from almost all independent variables. In other words, the model can be assumed to be fine.

Simultaneous Significance Test. This type of testing is performed using a statistical likelihood ratio (LR) value analysis in the logit model. The purpose of this test is to observe, at the same time, the impact of the independent variable on the dependent variable.

The LR decision-making ratio can be understood from the probability (p-value). The p-value is less than $\alpha$, which means that HO (null hypothesis) is rejected and Ha (hypothesis alternative) is accepted. It means that the equation model's independent variables simultaneously have a significant influence on the dependent variable.

Partial Significance Test. It separately observes whether an independent variable shows a significant effect on the dependent variable. In the logit model, the partial significance test approach is the normal standard approach, so the test criteria use the $\mathrm{z}$ value. The criteria for acceptance of the hypothesis in the z-test are: (1) If probability $<\alpha$, then $\mathrm{H}_{0}$ is rejected while Ha is accepted. In conclusion, there is a significant influence between the independent variable and the dependent variable. (2) If probability $<\alpha$, then $\mathrm{H}_{0}$ is accepted while $\mathrm{Ha}$ is rejected. In other words, there is no significant effect between the independent variables on the dependent variable.

\section{Statistical Test Results}

The descriptive statistical results table is given below: 
Table 1. Descriptive Statistics Results

\begin{tabular}{l|c|c|c|c|c}
\hline & $\begin{array}{c}\text { Profitability } \\
\left(\mathbf{X}_{\mathbf{1}}\right)\end{array}$ & $\begin{array}{c}\text { Financial } \\
\text { Leverage }\left(\mathbf{X}_{\mathbf{2}}\right)\end{array}$ & $\begin{array}{c}\text { Dividend } \\
\text { Policy }\left(\mathbf{X}_{\mathbf{3}}\right)\end{array}$ & $\begin{array}{c}\text { Firm size } \\
\left(\mathbf{X}_{\mathbf{4}} / \mathbf{X}_{\mathbf{m}}\right)\end{array}$ & $\begin{array}{c}\text { Income } \\
\text { Smoothing } \\
(\mathbf{Y})\end{array}$ \\
\hline Mean & 0.110023 & 0.384547 & 0.480571 & 28.89541 & 0.605263 \\
\hline Maximum & 0.921000 & 0.807310 & 2.248690 & 32.20096 & 1.000000 \\
\hline Minimum & 0.000780 & 0.131980 & 0.074030 & 25.79861 & 0.000000 \\
\hline Std. Dev. & 0.127525 & 0.176939 & 0.396792 & 1.515055 & 0.490952 \\
\hline Observations & 114 & 114 & 114 & 114 & 114 \\
\hline
\end{tabular}

Descriptive statistics describe research objects such as the average or mean value, maximum value, minimum value, and standard deviation. The profitability has a mean of 0.110023 , a median of 0.370000 , a maximum value of 0.921000 , a minimum value of 0.000780 , and a standard deviation of 0.127525 . Financial leverage has a mean value of 0.384547 , a maximum value of 0.807310 , a minimum value of 0.131980 , and a standard deviation of 0.176939 . The dividend policy has a mean of 0.480571 , a maximum value of 2.248690, a minimum value of 0.074030 , and a standard deviation of 0.396792 . Firm size has a mean value of 28.89541 , a maximum value of 32.20096 , a minimum value of 25.79861, and a standard deviation of 1.515055. Income smoothing has a mean of 0.605263, a maximum value of 1.000000 , a minimum value of 0.000000 , and a standard deviation of 0.490952 .

The Coefficient of Determination Results (McFadden $\mathbf{R}^{\mathbf{2}}$ ). The determination coefficient McFadden R2 tests how much variance of independent variables (including profitability, financial leverage, and dividend policy) can describe income smoothing as a dependent variable. The 'McFadden $\mathrm{R}^{2}$ coefficient of determination' also calculates the degree of variance of the independent variables, including profitability, financial leverage, and dividend policy, explaining the dependent variable on income smoothing after being moderated by firm size. 
Table 2. Logistic Regression Analysis Test Results Without Moderation

\begin{tabular}{|c|c|c|c|c|}
\hline Variable & Coefficient & Std. Error & z-Statistic & Prob. \\
\hline $\mathrm{C}$ & 0.781179 & 0.578766 & 1.349731 & 0.1771 \\
\hline PROF & -6.046121 & 2.235440 & -2.704667 & 0.0068 \\
\hline LEV & -0.173376 & 1.152550 & -0.150428 & 0.8804 \\
\hline DPR & 0.806075 & 0.693843 & 1.161754 & 0.2453 \\
\hline McFadden R-squared & 0.067653 & & 0.605263 \\
\hline S.D. dependent var & 0.490952 & \multicolumn{2}{|c|}{ S.E. of regression } & 0.469208 \\
\hline Akaike info criterion & 1.321049 & \multicolumn{2}{|c|}{ Sum squared resid } & 24.21723 \\
\hline Schwarz criterion & 1.417056 & \multicolumn{2}{|c|}{ Log-likelihood } & -71.29979 \\
\hline Hannan-Quinn criter. & 1.360013 & \multicolumn{2}{|l|}{ Deviance } & 142.5996 \\
\hline Restr. deviance & 152.9469 & \multicolumn{2}{|c|}{ Restr. log-likelihood } & -76.47346 \\
\hline LR statistic & 10.34735 & \multicolumn{2}{|c|}{ Avg. log-likelihood } & -0.625437 \\
\hline Prob(LR statistic) & 0.015833 & & & \\
\hline Obs with Dep $=0$ & 45 & \multirow{2}{*}{\multicolumn{2}{|c|}{ Total obs }} & \multirow[t]{2}{*}{114} \\
\hline Obs with Dep=1 & 69 & & & \\
\hline
\end{tabular}

It is known that the 'McFadden $\mathrm{R}^{2}$ coefficient of determination' is 0,067653 . It indicates that the independent variables profitability, financial leverage, and dividend policy can explain the variation in income smoothing (dependent variable) of $6.77 \%$. The rest is explained by other factors outside the variables studied.

Table 3. Logistic Regression Analysis Test Results with Moderation

\begin{tabular}{|c|c|c|c|c|}
\hline Variable & Coefficient & Std. Error & z-Statistic & Prob. \\
\hline $\mathrm{C}$ & -46.88860 & 19.32688 & -2.426083 & 0.0153 \\
\hline PROF & 304.0908 & 92.23531 & 3.296902 & 0.0010 \\
\hline LEV & 48.69824 & 33.14467 & 1.469263 & 0.1418 \\
\hline DPR & 31.87662 & 10.61810 & 3.002102 & 0.0027 \\
\hline FIRMSIZE & 1.696824 & 0.691543 & 2.453679 & 0.0141 \\
\hline PROF_FIRMSIZE & -10.99565 & 3.299328 & -3.332693 & 0.0009 \\
\hline LEV_FIRMSIZE & -1.748626 & 1.170338 & -1.494121 & 0.1351 \\
\hline DPR_FIRMSIZE & -1.049876 & 0.362743 & -2.894272 & 0.0038 \\
\hline McFadden R-squared & 0.230570 & \multicolumn{2}{|c|}{ Mean dependent var } & 0.605263 \\
\hline S.D. dependent var & 0.490952 & \multicolumn{2}{|c|}{ S.E. of regression } & 0.434723 \\
\hline Akaike info criterion & 1.172649 & \multicolumn{2}{|c|}{ Sum squared resid } & 20.03233 \\
\hline Schwarz criterion & 1.364663 & \multicolumn{2}{|l|}{ Log-likelihood } & -58.84097 \\
\hline Hannan-Quinn criter. & 1.250576 & \multicolumn{2}{|l|}{ Deviance } & 117.6819 \\
\hline Restr. deviance & 152.9469 & \multicolumn{2}{|c|}{ Restr. log-likelihood } & -76.47346 \\
\hline LR statistic & 35.26498 & \multicolumn{2}{|c|}{ Avg. log-likelihood } & -0.516149 \\
\hline Prob(LR statistic) & 0.000010 & & & \\
\hline Obs with Dep $=0$ & 45 & \multirow{2}{*}{\multicolumn{2}{|c|}{ Total obs }} & \multirow[t]{2}{*}{114} \\
\hline Obs with Dep=1 & 69 & & & \\
\hline
\end{tabular}


It is known that the coefficient of determination McFadden $R^{2}$ is 0,230570 . The independent variable profitability, financial leverage, and dividend policy with the moderating variable firm size can explain the income smoothing variable's variation by $23.06 \%$. In contrast, the rest is explained by the presence of other factors outside the variables studied.

Simultaneous Significance Test Results. Simultaneous significance test uses statistical likelihood ratio (LR) value analysis, which aims to collectively observe whether there is an effect of independent variables on the dependent variable.

Based on the Likelihood Ratio test without moderation, the probability value ( $p$-value) $<\alpha=0.05$, which is equal to 0.015833 , so it can be interpreted that Ho is rejected and vice versa $\mathrm{Ha}$ is accepted. It means that profitability $\left(\mathrm{X}_{1}\right)$, financial leverage $\left(\mathrm{X}_{2}\right)$, and dividend policy $\left(\mathrm{X}_{3}\right)$ simultaneously affect the income smoothing $(\mathrm{Y})$ in the company.

Based on the Likelihood Ratio test with moderation, the probability value (p-value) $<\alpha=0.05$, which is equal to 0.000010 , so it can be interpreted that Ho is rejected and on the contrary, $\mathrm{Ha}$ is accepted. It means that profitability $\left(\mathrm{X}_{1}\right)$, financial leverage $\left(\mathrm{X}_{2}\right)$, and dividend policy $\left(\mathrm{X}_{3}\right)$ simultaneously affect the practice of income smoothing $(\mathrm{Y})$ in companies with firm size $\left(\mathrm{X}_{4} / \mathrm{X}_{\mathrm{m}}\right)$ as moderating variables.

Partial Significance Test Results. The partial significance test looks separately at whether an independent variable significantly affects the dependent variable. In the logit model, the standard approach is used in the partial significance test, so that as the testing criterion, we use the $\mathrm{z}$ value.

Based on the $\mathrm{z}$ test results, the probability value of the profitability variable $\left(\mathrm{X}_{1}\right)$ proxied by return on assets is 0.0068 . This probability value is smaller than $\alpha(0.05)$, meaning that profitability $\left(\mathrm{X}_{1}\right)$ has a significant and negative effect on income smoothing (Y).

The probability value of the financial leverage variable $\left(\mathrm{X}_{2}\right)$ as proxied by the debt to total asset ratio is 0.8804 . As the value is greater than $\alpha(0.05)$, this means financial leverage $\left(\mathrm{X}_{2}\right)$ does not have a significant effect on income smoothing $(\mathrm{Y})$.

The probability value of the dividend policy variable $\left(\mathrm{X}_{3}\right)$, as proxied by the dividend payout ratio, is 0.2453 . The value is greater than $\alpha(0.05)$, so dividend policy $\left(\mathrm{X}_{3}\right)$ has not affected income smoothing (Y) significantly.

The profitability variable with firm size moderation $\left(\mathrm{X}_{1}\right.$ and $\left.\mathrm{X}_{\mathrm{m}}\right)$ states a probability value of 0.0009 . The value is less than $\alpha=0.05$, so we can conclude an interaction between profitability and firm size $\left(\mathrm{X}_{1}\right.$ and $\left.\mathrm{X}_{\mathrm{m}}\right)$, which has a significant and negative effect on income smoothing (Y).

The financial leverage variable with the moderation of firm size $\left(X_{2}\right.$ and $\left.X_{m}\right)$ shows a probability value of 0.1351 , and this value is greater than $\alpha=0.05$. Thus, we can conclude an interaction between financial leverage and firm size (X2 and $\mathrm{Xm})$, which does not significantly affect income smoothing (Y).

The dividend policy variable with firm size moderation $\left(\mathrm{X}_{3}\right.$ and $\left.\mathrm{X}_{\mathrm{m}}\right)$ shows a probability value of 0.0038 , which is smaller than $\alpha=0.05$. Hence, it can be concluded that there is an interaction between dividend policy and firm size $\left(\mathrm{X}_{3}\right.$ and $\left.\mathrm{X}_{\mathrm{m}}\right)$, which has a significant negative effect on income smoothing (Y). 
The probability value of the moderating variable firm size $\left(\mathrm{X}_{4}\right)$, proxied by $\log \mathrm{n}$ of total assets, is 0.0141 , and is smaller than $\alpha(0.05)$. We can conclude that firm size $\left(\mathrm{X}_{4}\right)$ positively and significantly affect income smoothing (Y).

Based on the logistic regression test conducted on the variable profitability $\left(\mathrm{X}_{1}\right)$, financial leverage $\left(\mathrm{X}_{2}\right)$, and dividend policy $\left(\mathrm{X}_{3}\right)$ on income smoothing $(\mathrm{Y})$, a logistic equation is obtained, namely:

$$
\ln \left[\frac{\mathrm{Pi}}{1-\mathrm{Pi}}\right]=0,781-6,046 \mathrm{X} 1-0,173 \mathrm{X} 2+0,806 \mathrm{X} 3
$$

Based on the logistic regression test carried out on the profitability variable $\left(\mathrm{X}_{1}\right)$, financial leverage $\left(\mathrm{X}_{2}\right)$, and dividend policy $\left(\mathrm{X}_{3}\right)$ towards income smoothing $(\mathrm{Y})$ with firm size $\left(\mathrm{X}_{4} / \mathrm{X}_{\mathrm{m}}\right)$ as the moderating variable in table 4.11 , the logistic equation is obtained, namely:

$$
\begin{aligned}
& \ln \left[\frac{\mathrm{Pi}}{1-\mathrm{Pi}}\right]=-46.889+304,091 \mathrm{X} 1+48,698 \mathrm{X} 2+31,877 \mathrm{X} 3+1,697 \mathrm{X} 4-10,996 \mathrm{X} 1 . \mathrm{Xm}- \\
& 1,749 \text { X2.Xm - 1,050 X3. Xm }
\end{aligned}
$$

\section{DISCUSSION}

The profitability shows a regression coefficient of -6.046121 and a probability value of 0.0068 . The regression coefficient value shows a positive effect of profitability on income smoothing. The probability profitability value of 0.0068 is less than $\alpha=0.05$ to conclude that profitability has a significant effect on income smoothing. The result is $\mathrm{H}_{1}$ rejected, which means that profitability has not positively and significantly affected income smoothing in manufacturing companies listed on the Indonesia Stock Exchange from 2016 to 2018. Studies undertaken by (Indrawan et al., 2018) backs the findings of this analysis, which indicates that profitability has a significant and negative effect on income smoothing. However, the study results conducted by (Doraini and Wibowo, 2017) and (Puspitasari and Putra, 2018) indicate a different outcome from that of this study.

Financial leverage has a regression coefficient of -0.173376 and a probability value of 0.8804 . This regression coefficient value provides information that financial leverage has negatively affected income smoothing. The probability value of financial leverage is 0.8804 and is greater than $\alpha=0.05$. Thus, we conclude that financial leverage does not significantly affect income smoothing. These results also result in $\mathrm{H}_{2}$, which states that financial leverage has a positive and significant effect on income smoothing in listed manufacturing companies listed on the Indonesia Stock Exchange from 2016 to 2018, being rejected. The results of this study are supported by research from (Juniarta and Sujana, 2015), but research by (Widhyawan and Dharmadiaksa, 2015) and (Fatmawati and Djajanti, 2015) show different results.

The dividend policy has a regression coefficient of 0.806075 and a probability value of 0.2453 . This regression coefficient value states that dividend policy affects income smoothing positively. The probability value for dividend policy is 0.2453 and is greater than $\alpha=0.05$. It means that the dividend policy does not significantly affect income smoothing. Thus, we can state the hypothesis $\mathrm{H}_{3}$, which states that dividend policy has a positive and significant impact on income smoothing in manufacturing companies listed on the Indonesia Stock Exchange from 2016 to 2018, is also rejected. The results of this study are in line with 
research by (Widhyawan and Dharmadiaksa, 2015) and (Doraini and Wibowo, 2017), while the study results do not follow the results of research conducted by (Yulfita, 2014).

Firm size has a regression coefficient of 1.696824 , with a probability value of 0.0141 . The regression coefficient value shows that firm size has a positive effect on income smoothing. The firm size probability value of 0.0141 is less than $\alpha=0.05$. It means that firm size has a significant effect on income smoothing. These results conclude that the $\mathrm{H}_{4}$ hypothesis, which states that firm size has a positive and significant effect on income smoothing in the listed manufacturing companies, is accepted. The results of this study follow the results of research conducted by (Doraini and Wibowo, 2017) but are different from the results of research by (Sonadi, 2018).

The interaction between profitability and firm size shows a regression coefficient of 10.99565 with a probability value of 0.0009 . The regression coefficient value shows that firm size has a negative effect on the relationship between company profitability and its income smoothing. The probability value for the interaction between profitability and firm size is 0.0009 , which is smaller than $\alpha=0.05$. It means that firm size has a significant effect on the relationship between profitability and income smoothing negatively. In other words, firm size weakens the level of influence of profitability on income smoothing. These results can be interpreted that the hypothesis $\mathrm{H}_{5}$, which states that firm size strengthens the effect of profitability on income smoothing in the listed manufacturing companies on the Indonesia Stock Exchange from 2016 to 2018, is rejected. The study results by (Paramita and Isarofah, 2016) indicated the other way around.

The interaction between financial leverage and firm size shows a regression coefficient of -1.748626 with a probability value of 0.1351 . The regression coefficient value shows that firm size has a negative effect on the relationship between financial leverage and income smoothing. The probability value for the interaction between financial leverage and firm size is 0.1351 and is greater than $\alpha=0.05$. It means that the firm size has no significant effect on the relationship between financial leverage and income smoothing negatively. This result means that the hypothesis $\mathrm{H}_{6}$, which states that firm size strengthens the effect of financial leverage on income smoothing in manufacturing companies listed on the Indonesia Stock Exchange from 2016 to 2018, is rejected. The results of this study are not in accordance with the research conducted by (Vivian, 2015).

The interaction between dividend policy and firm size has a coefficient of regression -1.049876 with a probability value of 0.0038 . The regression coefficient value shows that firm size has a negative effect on the relationship between dividend policy and income smoothing. The probability value for the interaction between profitability and firm size is 0.0038 , smaller than $\alpha=0.05$. It means that firm size has a significant effect on the relationship between dividend policy and income smoothing negatively. In other words, firm size weakens the effect of dividend policy on income smoothing. This result means that the hypothesis $\mathrm{H}_{7}$, which states that firm size strengthens the effect of dividend policy on income smoothing in the listed manufacturing companies on the Indonesia Stock Exchange from the period 2016 to 2018, is also rejected. However, different results are shown in research conducted by (Paramita and Isarofah, 2016). 


\section{CONCLUSION}

This study examines the effect of profitability, financial leverage, and dividend policy on income smoothing. It investigates whether firm size moderates in manufacturing listed companies on the Indonesia Stock Exchange in 2016-2018. The results indicated that profitability has a significant negative effect on income smoothing, financial leverage, and dividend policy does not significantly affect income smoothing; firm size has a significant positive effect on income smoothing. Then, firm size weakens the effect of profitability and dividend policy on income smoothing but does not moderate the influence of financial leverage on income smoothing.

There are limitations in this study because the sample used in this study is relatively short, namely for only three years (2016-2018 period). The use of three independent variables (profitability, financial leverage, and dividend policy) in this study, as well as one moderating variable firm size, in which the sample of companies used in this study is limited to manufacturing companies only, can be considered less reflective of companies engaged in another field.

With several limitations as attached above, some suggestions can be applied when conducting subsequent research regarding dividend policy. First, we can expand the observation period (more than three years). Second, we can add several other variables that may affect income smoothing. Last, we can expand the scope of research samples that are not only fixated on manufacturing companies. Thus, the next research is expected to have a broad perspective, and the results of the research can be more accurate and targeted.

\section{REFERENCES}

Dewantari, Ni Putu Santi. and I Dewa Nyoman Badera. (2015). Good Corporate Governance, Ukuran Perusahaan, dan Financial Leverage sebagai Prediktor Perataan Laba. E-Jurnal Akuntansi Universitas Udayana, 10(2), 538-553.

Doraini, Saadatut Azizi dan Seto Sulaksono Adi Wibowo. (2017). Pengaruh Ukuran Perusahaan, Kebijakan Dividen, Kinerja Keuangan dan Konvergensi IFRS Perusahaan terhadap Tindakan Income Smoothing pada Perusahaan yang Terdaftar di

Bursa Efek Indonesia. Journal of Applied Accounting and Taxation, 2(2), 187-197.

Fatmawati dan Atik Djajanti. (2015). Pengaruh Ukuran Perusahaan, Profitabilitas dan

Financial Leverage terhadap Praktik Perataan Laba pada Perusahaan Manufaktur yang

Terdaftar di Bursa Efek Indonesia. Perbanas Institute Repository, 1-20.

Ghozali, Imam. (2011). Manajemen Risiko Perbankan. Semarang: Badan Penerbit Universitas Diponegoro.

Ghozali, Imam. dan Dwi Ratmono. (2013). Analisis Multivariate dan Ekonometrika. Semarang: Badan Penerbit Universitas Diponegoro.

Gujarati, Damodar N. dan Dawn C. Porter. (2012). Dasar-dasar Ekonometrika Edisi 5. Jakarta: Salemba Empat.

Handoyo, Sigit and Safri Fathurrizki. (2018). Management Dysfunctional Behaviour toward Financial Statements: Income Smoothing Practice in Indonesia's Mining Industry Sector. Jurnal Keuangan dan Perbankan, 22(3), 429-442.

IAI. (2017). Standar Akuntansi Keuangan. Jakarta: IAI. 
Indrawan, Veronica; Sukrisno Agoes; Hisar Pangaribuan, and Oluwatoyin Muse Johnson Popoola. (2018). The Impact of Audit Committee, Firm Size, Profitability, and Leverage on Income Smoothing. Indian-Pacific Journal of Accounting and Finance (IPJAF), 2(1), 61-74.

Juniarta, I Wayan Agus dan I Ketut Sujana. (2015). Pengaruh Financial Leverage pada Income Smoothing dengan Good Corporate Governance sebagai Variabel Pemoderasi. E-Jurnal Akuntansi Universitas Udayana, 11(3), 921-939.

Kasmir, S.E., M.M. (2015). Bank dan Lembaga Keuangan Lainnya Edisi Revisi. Jakarta: Raja Grafindo Persada.

Kuncoro, Mudrajad. (2001). Metode Kuantitatif (Teori dan Aplikasi untuk Bisnis dan Ekonomi). Yogyakarta: Unit Penerbit dan Percetakkan AMP YKPN.

Mathews, M. R., and M. H. B. Perera. (1996). Accounting Theory \& Development. South Melbourne: McPherson's Printing Group.

Nachrowi, Nachrowi Djalal. (2006). Pendekatan Populer dan Praktis Ekonometrika untuk Analisis Ekonomi dan Keuangan. Jakarta: LPFE Universitas Indonesia.

Paramita, Ratna Wijayanti Daniar dan Isarofah. (2016). Income Smoothing: Apakah Ukuran Perusahaan Memoderasi? Jurnal Riset dan Aplikasi: Akuntansi dan Manajemen, 2(1), 55-64.

Puspitasari, Ni Kadek Budi dan I Made Pande Dwiana Putra. (2018). Pengaruh Profitabilitas pada Praktik Perataan Laba dengan Struktur Kepemilikan sebagai Variabel Pemoderasi. E-Jurnal Akuntansi Universitas Udayana, 23(1), 211-239.

Rachman, F. F. (2018). Bank Bukopin Permak Laporan Keuangan, Ini Kata BI dan OJK di https://finance.detik.com/moneter/d-3994551/bank-bukopin-permak-laporankeuangan-ini-kata-bi-dan-ojk (akses 22 September 2019).

Schroeder, Richard G., Myrtle W. Clark, and Jack M. Cathey. (2010). Financial Accounting Theory and Analysis: Text and Cases. New Jersey: John Wiley \& Sons, Inc.

Scott, William R. (2014). Financial Accounting Theory. Canada: Pearson Education.

Sonadi. (2018). Pengaruh Ukuran Perusahaan, Profitabilitas, Financial Leverage, dan Nilai Perusahaan terhadap Praktik Perataan Laba. Eprints Universitas Muhammadiyah Surakarta, 1-17.

Vivian, Narumondang Bulan Siregar. (2015). Analisis Pengaruh Rasio Keuangan terhadap Income Smoothing dengan Ukuran Perusahaan sebagai Variabel Moderating pada Perusahaan Perkebunan yang Terdaftar di Bursa Efek Indonesia dan Bursa Malaysia. Simponium Nasional Akuntansi 18 Medan.

Widhyawan, I Made Indra. dan Ida Bagus Dharmadiaksa. (2015). Pengaruh Financial Leverage, Dividend Payout Ratio, dan Penerapan Corporate Governance terhadap Praktik Perataan Laba. E-Jurnal Akuntansi Universitas Udayana, 13(1), 157-172.

Wild, John J., K. R. Subramanyam, and Robert F. Halsey. (2013). Financial Statement Analysis. New York: McGraw-Hill Education.

Wolk, Harry I., Jere R. Francis, and Michael G. Tearney. (1992). Accounting Theory: A Conceptual and Institutional Approach. Ohio: South-Western Publishing Co.

Yulfita, Dewi. (2014). Pengaruh Profitabilitas, Kebijakan Dividen, dan Pertumbuhan Perusahaan terhadap Praktik Perataan Laba. E-Journal Universitas Negeri Padang, 2(2), 1-31.

Situs (Website) Resmi Bursa Efek Indonesia : https://www.idx.co.id 